\title{
SEXUALLY TRANSMITTED DISEASES PREVENTIVE BEHAVIOR AMONG FEMALE SEX WORKERS
}

\author{
Dwi Retnaningsih*, MY Martini, Windyastuti Windyastuti \\ Nursing Science Program STIKES Widya Husada Semarang \\ Jl. Subali Raya No. 12 Krapyak Semarang, Telp 024-7612988-7612944 \\ Email : dwiretnaningsih1@yahoo.co.id
}

\begin{abstract}
Introduction: Sex workers and their customers are the high risk group population that potentially transmitting sexually transmitted diseases including Human Immunodeficiency Virus (HIV). This research aims to describe the preventive behavior of female sex workers in preventing transmission of STDs and HIV in Gambilangu Semarang Localization. Methods: This research was qualitative study, The 5 participants of this study were female sex workers who still active in Localization within the period of 2016-2017. Results: The behavior of female sex workers on the prevention of STDs and HIV, were identified as: all participants always offered condoms to cliens before sexual transactions, all the participants negotiated the clients to use condom before having sexual intercourse, all participants rejected firmly to have sex with the client suspected having STDs yet reluctan to use condoms, most participants washed the vagina using betel soap, consuming herbs and antibiotics without a medical prescription that they believed it could prevent STDs.
\end{abstract}

Keywords: female sex workers, behavior, sexual transmitted disease, localization

\section{INTRODUCTION}

STDs (sexually transmitted diseases) or veneral disease are the disease that transmitted by sex. STDs includes Syphilis, Gonorrhea, Bubo, Jengger Ayam, and Herpes (Central Java Province Health Profile, 2013). STDs or STIs (Sexually transmitted infection) affect more than 15 million people in the United States. Prevalence can be attributed to high-risk sexual behavior (unprotected sex or high-risk partner selection) (Salvo, 2014). Indonesia ranks fourth in the world's largest population level, showing how rapidly STIs can thrive. Commercial sex is an important factor in the spread of STIs can not be separated with prostitution conditions that exist in Indonesia. Research in several regions in Indonesia shows high levels of risk behavior and STI cases among male and female sex workers.

In addition to Syphilis, Gonorrhea, Bubo, Jenger Chickens and Herpes, HIV (Human Immuno Deficiency Virus) and AIDS (Acquired Immuno Deficiency Syndrome) are also one of the STIs. HIV and AIDS is a contagious disease caused by a viral infection that attacks the immune system. These infections cause the patient to experience a decrease in body resistance so it is very easy to be infected by various other diseases (Health Profile of Central Java Province, 2014).

The current prevalence of HIV and AIDS tends to increase rapidly. According to ASEAN's first ASEAN Regional report on HIV and AIDS in 2011, "addresing AIDS in ASEAN Region", 1.5 million people are estimated to be living with distributed HIV among the AMS (ASEAN Member States). Indonesia ranks fourth in the world's largest population level, showing how rapidly STIs can develop. Commercial sex is an important factor in the spread of STIs can not be separated with prostitution conditions that exist in Indonesia. Research in several regions in Indonesia shows high levels of risk behavior and STI cases among male and female sex workers.

CDC New HIV Infections in the United States (2016), reports an information on how HIV is transmitted for ages 13-24, through $63 \%$ homosexual, $25 \%$ sexual hetero, intravenous needle intravenous drug users $8 \%$, and MSM (Men who have sex with Men) IDU (Intravena Drug Use) 3\%. Seeing a large enough chance of HIV transmitted through sexual intercourse, coupled couples relationship is a special factor to watch out for. Commercial sex has become an important factor in the spread of HIV, especially in Asia. 
Sex workers can work in a variety of forms, may be localized to be registered under medical supervision or commonly referred to as direct sex workers or indirect sex workers who are indirect sex workers who get clients from the street or while working in entertainment venues such as nightclubs, massage parlors, discotheques, Cafe, karaoke or bar.

One of the protective devices of transmission of STIs, HIV and AIDS in sexual relations is the use of condoms. Female sex workers are likely to have low rates of condom use. Sex workers have also reported experiencing violence from clients that could lead to an increased risk of HIV transmission. In addition, the use of alcohol before or during sex has been associated with an increase in unprotected sex cases, which would increase the risk of HIV transmission (2016: 1).

Central Java Province the number of HIV infections reported in 2015 were 1,074 cases. The number of deaths due to AIDS in Central Java in 2015 was 126 cases, more than in 2011 which was 89 cases (Health Profile of Central Java Province, 2015: 45). Ministry of Health survey results show that until 2012 has found 267 cases of AIDS in the city of Semarang. Semarang ranks first for Central Java in the number of people with HIV and AIDS (Health Profile of Central Java Province, 2013: 19).

Cases of STIs, particularly in the number of cases of Syphilis in Central Java in 2014 were 907 cases. Most of age group was started by age group of 25-49 years old 535 cases $(58,99 \%)$, followed by age group $20-24$ year 259 cases $(28,56 \%)$ (Health Profile of Central Java Province 2014: 22). The number of new cases of STIs in the Province of Central Java in 2013 is 10,479 cases, higher than in 2012 of 8,671 cases. (Health Profile of Central Java Province, 2013: 20).

The result of preliminary study in Gambilangu localization got data of total number of FSWs (Female Sex Workers) is 140 people. Three FSWs interviewed found that FSWs did not use condoms due to several reasons, such as 2 FSWs did not offer condoms to their customers, 1 FSWs said they did not use condoms because it's not practical so that they afraid it make customers leaving.

Lack of condom use as one of the safeguard tools of STI prevention by FSWs in Gambilangu Semarang Localization which is known through preliminary study, and the existence of condom use data about $30 \%$ in connection with the issuance of mayor instruction about $100 \%$ Condom Use Program in 2 (two) localization in Semarang City Namely Sunan Kuning Localization and Gambilangu Localization, has not been successful in prevention of sexually transmitted diseases especially HIV and AIDS in the city of Semarang. Further research needs to be done to get information about the behavior of FSWson the prevention of STIs, HIV and AIDS. In this study, in addition to getting an idea of what percentage of sex worker women who use sex safety equipment, will also find things that affect the lack of condom use among women sex workers. Based on the things presented, the researchers feel this problem is important to be examined.

The purpose of this study was to determine the behavior of female sex workers in the prevention of STIs, HIV and AIDS, Identify the characteristics of FSWs, describe the behavior of FSWs and describe the perception of FSWs in Gambilangu Semarang Localization of STIs, HIV and AIDS.

\section{METHODS}

This research is a kind of descriptive qualitative research, with phenomenology approach. Population in this research is FSWs active in Localization of Gambilangu Semarang which is a technique of selecting 5 participants among the population as desired by researchers (research objectives or problems).

Table 1.1

The Characteristics of Participants

\begin{tabular}{ccccc}
\hline No & Code & Age & Education & Duration of work \\
\hline 1 & P-1 & 37 th & Junior High School & 6 th \\
2 & P-2 & 26 th & Elementary school & 2 th \\
3 & P-3 & 35 th & Elementary school & 5 th \\
4 & P-4 & 32 th & Elementary school & 3 th \\
5 & P-5 & 42 th & Elementary school & 7 th \\
\hline
\end{tabular}




\section{RESULTS}

1. Characteristics of FSWs in Localization Gambilangu Semarang.

The 5 participants dominated by middle adult age.

2. FSWs Behavior in Gambilangu Semarang Localization In Prevention of STIs, HIV and AIDS

a. The data as told by the participants about the difficulty of asking clients to use condoms. Interviews of all participants said it was difficult to ask clients to use condoms.

"Sulit... Misalkan 3 orang, satu aja udah mau pakai kondom, udah mau pakai kondom udah bagus." (P1).(Difficult..Example 3 person, One person use a condom, that's good...)

The reason customers do not use condoms is not comfortable and feel less satisfied using condoms, there are also clients who try to convince participants that he did not have venereal disease, so safe without a condom.

a. The data as told by the participants about the right to negotiate the use of condoms with client.

Interviews found that most of the participants said they had the right to use condoms.

"Ada kalo ngga ada ya saya ngga mau, misalkan: "Mbak bisa nawar mbak?" berapa? "Sekian..." pakai kondom ya mas? "Ah nggak usah ah" yah jangan gitu biar sama-sama enak. Ada yang mau ada yang ngga." (P1).

b. Response if the client does not want to use protective equipment (condoms) to prevent contracting / affected STIs, HIV and AIDS.

The results of the interview are all participants say if they have tried to seduce and the client's answer still does not want, then they are continue to provide sexual services.

"Ya.. kalau nggak mau menggunakan kondom ya gimana lagi ya kepaksa aku layanin, soalnya kan disini kan butuh duit." (P3).

c. Other ways than to use protective equipment (condoms)

The results of interviews there are some of the participants that admit in addition to using their condoms often consume herbs, as well as the use of betel soap, some are often using antibiotics when it feels scuffed on the genitals.

"Antibiotiknya biasanya

(menyebut sebuah merk), kalo jamu mah ya biasa jamu-jamuan. Pakai tiap hari (menyebut sebuah merk sabun sirih)."(P4).

d. Experience serving clients who are sick Interviews found that most participants said they had experience serving clients who were suffering from STIs, some of whom described symptoms that they suspected were STIs, as stink from the client's penis fluids different than usually.

"Ya pernah tapi pakek kondom, kalau dia nggak mau ya saya nggak mau mbak, kan keliatan mbak itu." (P5).

3. Perception of FSWs in Localization of Gambilangu Semarang on STI, HIV and AIDS

a. Knowledge of understanding IMS Interview results show that participants know what is meant by STIs, but most can not explain well the definition of STIs.

"Itukan penyakit kelamin." (P2)

b. Knowledge of STI symptoms

The results of interviews show that FSWs said that STI disease is painful when the BAK and pain.

"Gejalanya ya kadang ada yang panas dingin, kencingnya sakit, kadang juga ya nyerilah pokoknya." (PI)

c. Knowledge of STI transmission

Interviews of all participants said STIs can be transmitted through sexual contact, and some mention through unsafe sexual intercourse that is not using condoms and free sex or often bergonta pain.

"Kalo e, pokoknya kalok gak pakek pengaman, kalau gak pakek kondom bisa kena." (P3)

d. Knowledge of the types of STIs

The results of the interviews are all participants can not mention the full range of STIs.

"Ceker ayam, e.. GO, ...ibu menyusui, trus sif.. sif.. apa sifilis ya?" (P2)

e. Knowledge of STIs 
Interview results none of the participants could pinpoint the consequences of the STI.

"Ya kalo dibiarin ga disembuhin lama-lama bisa jadi HIV." (P3)

f. Knowledge of STI prevention

The results of the interviews were that all WPS said they used to take herbs and occasionally taking antibiotics.

"Memakai kondom kalau berhubungan seks, misalnya kalau udah terkena memeknya ya diobatin." (P1)

g. Knowledge of understanding HIV and AIDS

The results of the interviews show that FSWs do not really knows about HIV and AIDS.

"Ya tau namanya, tapi ga tau." (PI)

h. Knowledge of symptoms of HIV and AIDS

Interviews of most participants said they don't know the symptoms of HIV and AIDS.

"Gejala-gejalanya juga kurang tau aku." (P4)

i. Knowledge of how HIV and AIDS is spread

WPS can answer exactly how HIV and AIDS is transmitted.

"Dari jarum suntik, dari ibu menyusui, dari dari berhubungan seks tapi tanpa kondom." (P1)

j. Knowledge of the effects of HIV and AIDS

The results of the interviews were the consequences of HIV and AIDS death. None of the parties mentioning the immune decline.

"Meninggal." (P3)

k. Knowledge on how to prevent HIV and AIDS

The data as told by the participants said condom use was a good way to prevent HIV and AIDS.

"Itu kalau kena iya kalau berhubungan ya harus pakai kondom itu. " (P3)

1. FSWs Perceptions of Their Vulnerability to STIs, HIV and AID

The results of STIs, HIV and AIDS, STIs, HIV and AIDS.

"Iya, kalau disini sih rentan ya

kan pekerjaannya berhubungan badan." (P1)

\section{DISCUSSION}

\section{Characteristics of WPS in Localization Gambilangu Semarang}

The paricipants were 5 people consisting of different age backgrounds, age of participants ranged from the youngest 26 years old and the oldest 42 years. This is in the journal Women's Sex Workers Direct by Dewi Purnamawati in 2013, which has the characteristics of research subjects aged 23 to 45 years.

Most of the FSWs were elementary school graduates, only one participant had the last education of Junior High School. This is also the same as that of the Journal of Sexual Transmitted Disease Prevention Jump by Dewi Purnamawati in 2013, which has the characteristic of most subjects were elementary school graduates.

\section{WPS Behavior in Gambialngu Semarang Localization In Prevention of STI, HIV and AIDS}

Interviews about condoms use the commercial sex worker find it difficult to persuade customers to use condom during sex. Most of the customers won't using condom during sexual transaction, the uncertain and dependent on the clients themselves. This is in Prevention of STIs in Semarang City by Ratu Matahari 2012, that commercial sex worker find it difficult to persuade customers to use condom during sex. This is due to several circumstances: the weak bargaining position of sex workers with their customers, and customers usually provide excessive service rewards when sex workers are willing to have sex without using condoms.

Most participants said they had experience serving clients who were suffering from STIs. Participants dare to firmly ask the client to use condoms if the client looks like suffer STIs, if the client refuses then the participants prefer not to make sexual transactions.

Participants recognize in addition to using condoms they often consume herbs, betel soap and antibiotics when it feels blisters on the genitals. Only a small percentage of participants said they did not use anything for STI prevention other than using condoms. It is also found in the research journal of Qualitative Studies on Sexual Sex Worker Sexual Sexuality Perceptions and Prospects in STI Prevention in Semarang City by Ratu Matahari in 2012, where commercial sex 
workers are still trapped in the myths circulating in the community on how to prevention of STIs with natural or chemical ingredients. They often use the betel soap that circulates in the market and wash their vagina with hot water mixed with soft drinks.

\section{Perception of FSWs in Localization of Gambilangu Semarang on STI, HIV and AIDS}

Interviews show that participants' knowledge about STIs is poor. According to most participants, the STI is a venereal disease and can not explain further. Regarding the mode of transmission of STIs, it can be concluded knowledge of all participants either. The answers obtained from in-depth interviews similar of all participants, through unsafe sexual relations, not using condoms and free sex or often bergonta pair. In accordance with Verawaty \& Rahayu's theory (2011: 245), STIs can only be transmitted through unsafe sexual intercourse. Unsafe here is sex through the intercourse without a condom, unprotected sex through the rectum and oral sex. Results of interviews with participants on the understanding and symptoms of HIV and AIDS, lack of knowledge of pantisipan. Most participants said they did not know the symptoms of HIV and AIDS, a small percentage of participants believed someone who had had HIV for years would appear lethargic. Meanwhile, according to Price \& Wilson (2016: 224) symptoms of someone suffering from HIV that is rash, persistent fever, night sweats, diarrhea, weight loss.

All participants had good knowledge as a result of HIV AIDS. The average participant mentioned a mode of transmission that is through unsafe sex, some can even mention some other ways of transmission such as using a shared needle and breast milk from mothers who are HIV. Regarding the prevention of HIV and AIDS, participants have a good understanding, all participants are well aware of the importance of condoms to prevent the transmission of HIV and AIDS through sexual contact.

The results of interviews on the participants about the perception of susceptibility to STIs, HIV and AIDS, some clients say they feel vulnerable to STIs, HIV and AIDS, Some believe that he has done a good prevention, and always follow the screening so they feel not vulnerable to Contracting STIs, HIV and AIDS. Yet according to the journal Risk Factors Influential Against HIV and AIDS Incidence in Semarang and Surrounding by Tuti Susilawati 2010, the highest risk for HIV / AIDS infection is women who work as sex worker commercial. The results of the study in Moscow found that $79 \%$ of HIV-infected women were from sex worker groups.

\section{CONCLUSION}

Based on the results of research and discussion can be concluded as follows:

Participants' behavior in the Localization of Gambilangu Semarang in the prevention of STIs, HIV and AIDS ie, participants will try to seduce again when clients refuse to use condoms, participants dare to refuse sexual transactions to clients they suspect suffered from STIs but are unwilling to use condoms and the use of antibiotics, Washing and scraping the sex organs, consuming herbs and the use of sabunsirih.

The perception of WPS in the localization of Gambilangu Semarang on STIs, HIV and AIDS, in terms of the participants 'knowledge about STIs, HIV and AIDS is lacking, especially on the participants' knowledge about the understanding, the types, symptoms and consequences, while for the mode of transmission and prevention, Participants have a good understanding. Some participants have a perception that they are vulnerable to STIs, HIV and AIDS, while others are not vulnerable.

For Further Researchers, the researcher are suggested to conduct similar research by adding other methods such as FGD (Focus Group Discution) or Grounded theory, as well as interviewing customers from WPS so that the results achieved can be maximal.

\section{REFERENCES}

CDC National Center for HIV/AIDS, Viral Hepatitis, STD and TB Prevention. 2016. New HIV Infections in the United States. CDC Fact Sheet: New York.

Dinas Kesehatan Provinsi Jawa Tengah. 2013. Profil Kesehatan Provinsi Jawa Tengah Tahun 2013. Semarang: Dinkesjateng.

Dinas Kesehatan Provinsi Jawa Tengah. 2014. Profil Kesehatan Provinsi Jawa 
Tengah Tahun 2014. Semarang: Dinkesjateng.

Hindawi Publishing Coporation AIDS Research and Treatment. 2016. Prevalence of HIV Associated Risk of Sex Work among Youth in the slums ofKampala.

Matahari, Ratu. 2012. Studi Kualitatif Mengenai Persepsi dan Perilaku Seksual Wanita Pekerja Seks Komersial (PSK) dalam upaya pencegahan IMS di Kota Semarang. Jurnal Penelitian. Thailand: Mahidol University.

Moleong Lexy J. 2007. Metodologi Penelitian Kualitatif Edisi Revisi. Bandung: PT Remaja Rosdakarya.

Price Sylvia A. \& Wilson Lorraine M. 2016. Patofisiologi Konsep Klinis Proses Proses Penyakit Volume 1. Jakarta: Penerbit Buku Kedokteran EGC.
Purnamawati, Dewi. 2013. Perilaku Pencegahan Penyakit Menular Seksual di Kalangan Wanita Pekerja Seksual Langsung. Jurnal Penelitian. Karawang: Stikes Kharisma.

Salvo, Susan G. 2014. Mosby's Pathology For Massage Therapists Third Edition. China: Elsevier.

Susilawati, Tuti. 2010. Faktor - Faktor Risiko Yang Berpengaruh Terhadap Kejadian HIV dan AIDS di Semarang dan Sekitarnya. Jurnal Penelitian. Purworejo: Akademi Kebidanan Purworejo.

Verawaty Sri Noor \& Rahayu Liswidyawati. 2011. Merawat Menjaga Kesehatan Seksual Pria. Bandung: Grafindo Everybody's 